\title{
Infological models for smart commerce
}

\author{
Kirill A. Kniazev \\ Director, Netbell LLC; \\ Doctoral Student, Department of Innovation and Business in Information Technologies \\ National Research University Higher School of Economics \\ Address: 20, Myasnitskaya Street, Moscow, 101000, Russian Federation \\ E-mail: kk@netbell.ru
}

\section{Mikhail M. Komarov}

Associate Professor, Department of Innovation and Business in Information Technologies

National Research University Higher School of Economics

Address: 20, Myasnitskaya Street, Moscow, 101000, Russian Federation

E-mail:mkomarov@hse.ru

\section{Abstract}

In modern society, skills of working with information play a significant role. The influence of information in our everyday lives is rapidly increasing, while methods of data processing remain the same.

Research is being directed at problems of data processing and visualization of information, which become more popular with each year. This paper describes infological models, a new method of data visualization and information processing based on technologies of information presentation, as well as on principles of semantic networks, open data and data banks.

The technology of infological models represents a new approach to data storage and exchange which enables us to look at information processing in a new way. Based on principles of open data, semantic networks and data banks, the concept seeks to define the set of entities and relations, based on which an independent information block is displayed as a block diagram, which is easy to understand for an average user with a computer.

This work provides a brief overview of the information overload problem, describes the technology of infological models, its general principles and contains an application of mentioned methods in e-commerce using the example of knowledge bases, news portals, on-line shops, smart house and Internet of Things, with description of features and advantages, ending with an overall conclusion.

Key words: infological model, knowledge representation, smart commerce, semantics, visualization, open data, data banks, semantic networks.

Citation: Kniazev K.A., Komarov M.M. (2016) Infological models for smart commerce. Business Informatics, no. 4 (38), pp. 19-26. DOI: 10.17323/1998-0663.2016.4.19.26.

\section{Introduction}

A ccording to the Digital, Social and Mobile Report, in 2015 global network penetration exceeded $42 \%$, having increased by 7 percentage points over the previous year. Such a high rate of network penetration enables us to exchange a wealth of information, and a growing number of devices generates more and more data which we have to handle. Data will have to be managed so that the process of knowledge accumulation is not a problem. Attention is being increasingly focused on the issues of data visualization, interface intuitiveness and UI/UX design.

The denoted tendency makes network power accessible to new and inexperienced users. The technologies of semantic networks, open source data and data banks are changing the information management process. A new 
method of data visualization and information handling based on modern technologies of information representation, the philosophy of semantic networks, open data and data banks will be described within this study.

\section{Technology of infological models}

\subsection{Short description}

Infological models are a new intuitive way to visualize information which allows us to improve the perception, ergonomics and automated analysis of data through information presentation in the form of a human-readable, connected interactive graph. The technology is based on modern information and knowledge visualization methodologies and combines basic principles of semantic networks, open data and data banks.

\subsection{Implementation example 1: Events}

It is worth starting a detailed technology description with a review of a generic diagram of the infological model using the example of event sequence consisting of two subjects involved (Figure 1).

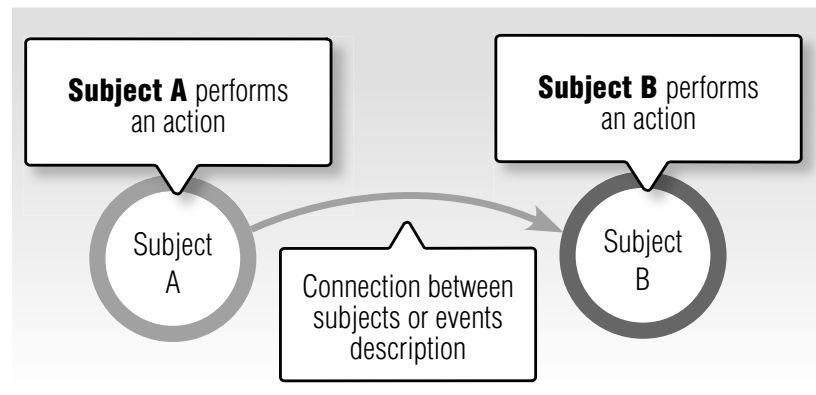

Fig. 1. Diagram of event sequence of two subjects

The left object on the diagram represents an action performed by subject $A$ which resulted in, gave rise to or transferred to the action performed by subject $\mathrm{B}$. The objective of the diagram is to outline a general narrative concept of news flow facilitating an advanced and controlled study of the information provided. Therefore, the above model not only organizes the text information, but also implements the basic principles of information visualization: a "top to bottom" approach [1], data flow control [2], model interactivity [3] and other means.

\subsection{Implementation example 2: Terms}

Let us consider the technology application using another example describing the terminology of a certain area of knowledge (Figure 2).

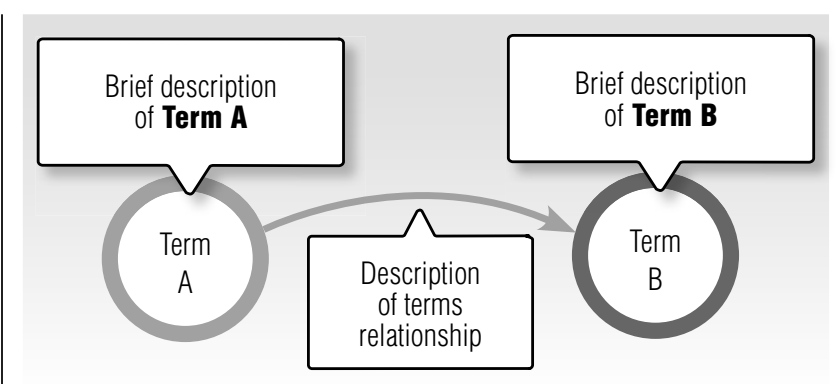

Fig. 2. Diagram of terminology with two terms

The left object in the diagram is a term describing an object in the infological model context. The right object is the second term, and the arrow in the middle also defines their relationship. The purpose of the diagram is to give us a general idea of the terminology structure and relationship of the terms, thereby placing the user into the target area of knowledge. Each term can be explained in detail by means of the model, and the user on his own is able to determine exactly which of the terms used he wants to be explained. This presentation of information not only visualizes the knowledge, but also enables the user to manage the data acquisition, moving from general concepts to more exact details.

Thus, infological models have a significant positive effect on the ergonomics of information received by the user, and so improve information handling [4, 5]. In addition, due to the micro-markup languages and serverbased parsing of the input data, an automated distribution of input data and their automatic analysis become possible, that is not only an embodiment of the semantic network, but also the implementation of the concepts described in the international data visualization research.

\subsection{System architecture}

The next figure provides an example of architecture based on which services can be deployed using infological models. A set of technologies in the framework of the architecture described is not a baseline minimum: for example, a separate server-based caching and separate databases: MS SQL and ORM-analogue, MongoDB are optional, but significantly improve the performance of the entire system (Figure 3).

\section{General principles}

Let's consider in more detail exactly what kind of principles of data handling as described in international studies can be realized through application of the technology of infological models. Within this section consideration will be given not only to engineering but also to the interface aspect of the technology. 


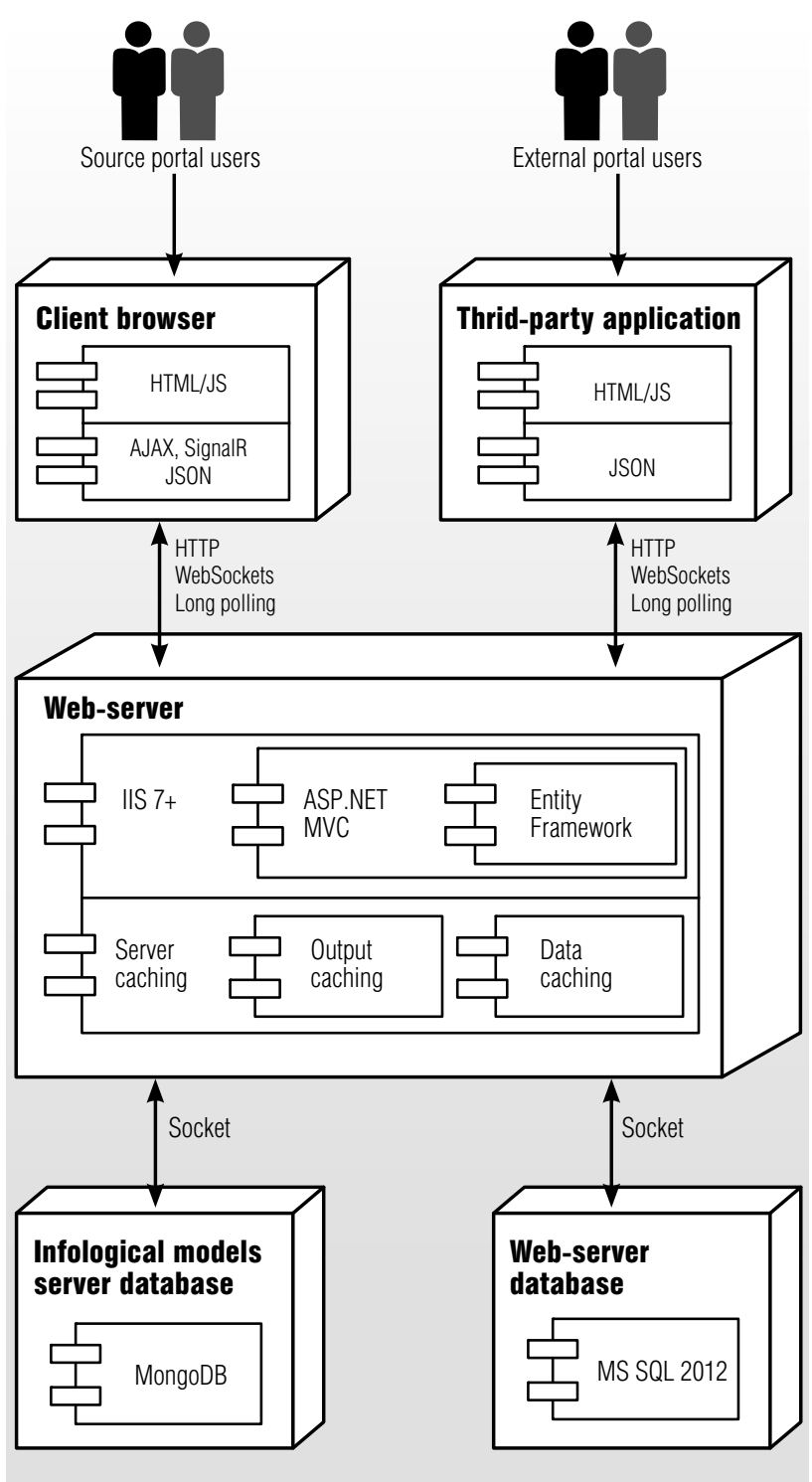

Fig. 3. Example of the system architecture

\subsection{Ergonomics}

Information visualization in infological models has its origin in the concept of semantic networks and the principles of the worldwide research (Figure 4).

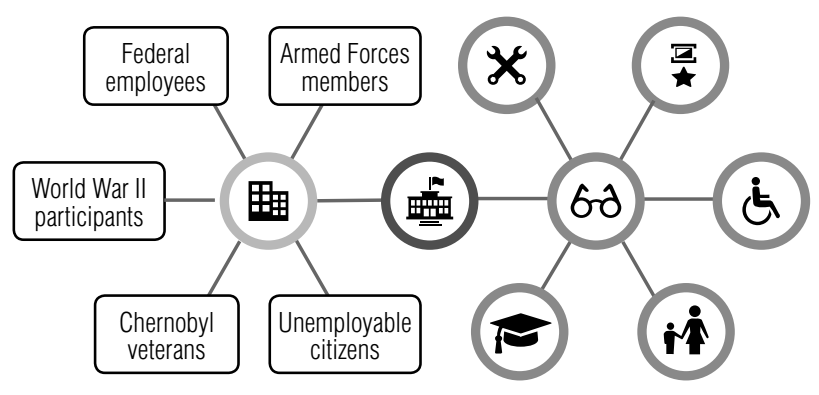

Fig. 4. Changes in state pension provisions
As exemplified by the above picture, it is obvious how application of an infological model can change the approach to information perception [3]. Let us consider the example in more detail: a law approved by the Government affects social payments to pensioners and public sector employees. Thus, a person not yet familiar with the law can already observe in the diagram if he is affected by the consequences. If a user belongs to one of the categories of citizens who are subject to operation of the law, a citizen can see the changes imposed by the law on welfare payments by moving the cursor to "its" icon or caption $[4,6]$.

Eventually, instead of studying 64 pages of the full text of the law, the user will get the required amount of information from an extract consisting of several sentences.

\subsection{Interactivity}

The interactivity, as written by Alan MacEachern in his studies $[3,7]$, is one of the main tools of qualitative computer information visualization. Infological models are inherently interactive, and each model element is available for user interaction.

When hovering a cursor over the model object, the user obtains an extensive description of the event or term represented by the object. Thereby, it becomes possible not only to develop the user's behavioral pattern teaching to predictable interaction with the model, but also to control his attention, highlighting the most important terms and/or events within the model [8] (Figure 5).

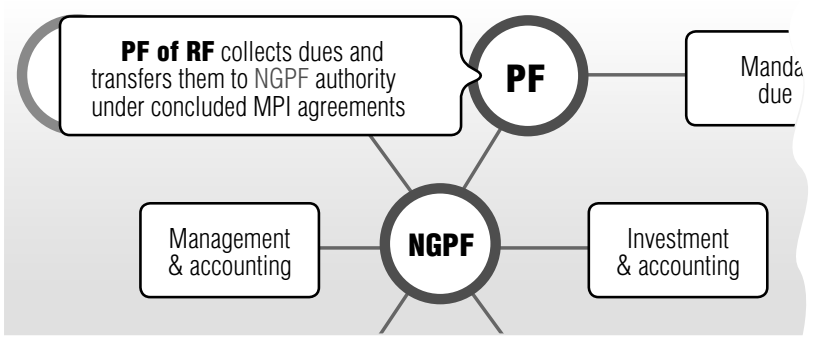

Fig. 5. Full description of the infological model's object

The example above shows a model fragment describing a reallocation of functions of the non-state pension provisions to market participants.

In addition to the general diagram representing the entire picture, hovering over the object reveals a detailed description of new features of the selected object, and also contains the link to the full description of the selected object with all the related information. Eventually, the user can first evaluate the picture as a whole, and then study the details through interaction with the model [9]. 


\subsection{Animation}

Animation is the primary way to "revive" the model and make a call for interaction addressed to the user [7]. But the most important thing is that animation makes the model narrative by default. Besides the afore-mentioned Alan MacEachren's studies, which describe the role of animation in terms of computer information visualization, we would like to pay special attention to Chris Baber's position determining the narrative nature of information by the basis of event chains [10].

The infological models are gradually shown to the user, in chronological order of occurrence of events or in hierarchical order of terms arrangement. From the first second this allows the user to understand the direction of the news flow and the order in which it is preferable to be studied (Figure 6).

As you can see by the example, the animated information output reveals the narrative aspect of infological models, records events in sequence, and above all makes it possible to control the user's attention with seemingly equivalent model objects.

\subsection{Automated information analysis}

With the help of predefined sets of stencils and information organization in the form of a semantic network, it becomes possible to analyze data automatically and accurately. Here are some examples of complicated reports which can be built automatically within the technology of infological models and applied in appropriate target areas:

$\checkmark$ activity of the President in the healthcare area during the last month;

$\checkmark$ the story of competitions and awards for any film at the cinema ceremony with referencearticles;

$\checkmark$ the share of legislators, initiated positive changes for unemployed citizens in pension market over the last year;

^ "conversional funnels" of social law enactment;

a host of other things.

166-FL "About state pension provision"

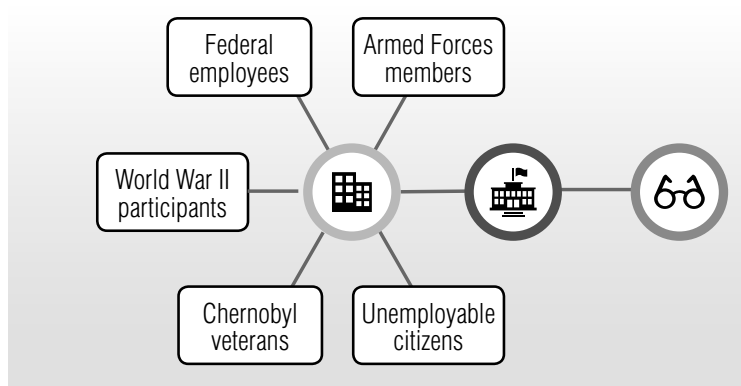

Fig. 6. Animated process of model appearance

\subsection{Automatic extraction of information fragments}

Structuring of used stencils and information systematization within the infological model make it possible to computerize not only the information analytics, but also extracts for the related articles.

Thus, for example, automatically extracted data can be placed within an article on any portal. Furthermore, owing to micro-markup languages, all information managed by the system remains accessible to search algorithms and is suitable for machine-readable use. As a result, we get export and data-sharing mechanisms for on-line services (Figure 7).

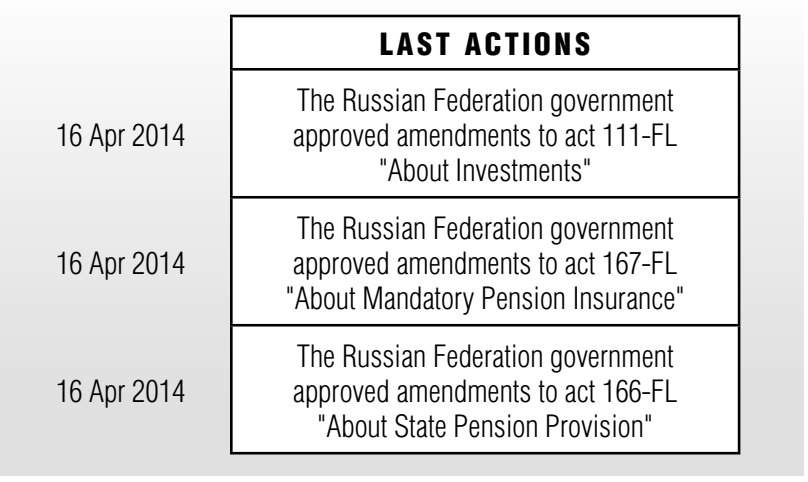

Fig. 7. Automatically formed list of Government acts

The example above reveals an automatic sampling of the latest acts of the Russian Government. Thus, provided that the base of infological models in the selected area is filled, a fully automated reporting and analysis of the subject actions described in the infological models are possible, that for the time of writing this paper is a unique feature of the solution.

\subsection{Integration with data sources}

Inasmuch as the technology of the infological models is associated with the visual methodology and notation of semantic markup, it can be integrated with the sources of dynamic data.

Moreover, the technology was developed with a longterm prospect of automated data generation: starting from uploading of the simplest news blocks from the open publishers and ending with the implementation in the smart house ecosystem, BI systems, etc. (Figure 8).

The example above shows the structural presentation of the infological models applied to a smart house. In particular, blue elements indicate the rooms which have operating devices; green elements indicate completely "switched off rooms". 


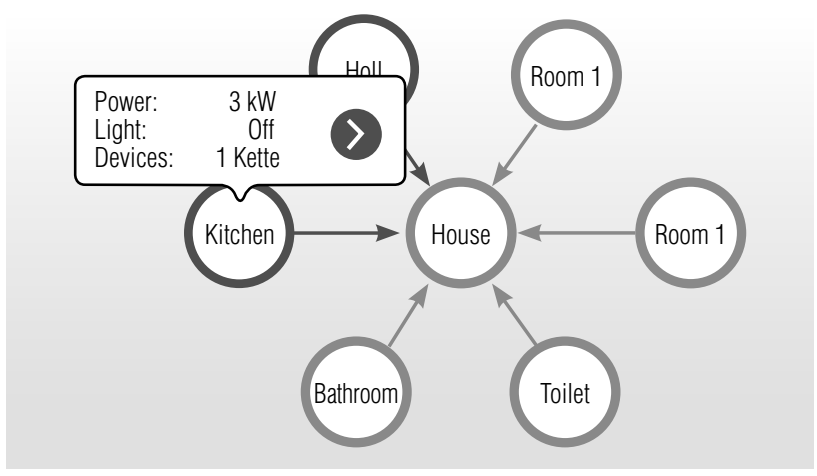

Fig. 8. Infological models in the scope of the smart house

By clicking a room, a data summary received from the connected sources is displayed and it becomes possible to go to an enlarged view of the room. In addition to information presented in the picture, interactive graphs and an enhanced navigation link can be arranged.

\section{Application of infological models in e-commerce}

Let us analyze the use of infological models as a tool of information visualization in the e-commerce environment.

\subsection{Information portals and knowledge bases}

Information visualization is a relevant task of the infological models. This makes the technology a powerful tool in the area of information portals and knowledge bases. Among the capabilities offered by the technology for information portals and knowledge bases, the most significant ones are the following:

- Data coherence. All terms and articles integrated into the system are interconnected. The models in which the content data is used are also combined into a single semantic network and available for automated analysis;

$\downarrow$ Data integrity. The data coherence determines the completeness of data provided to the user: it is easy to find descriptions of the adjacent terms, a detailed description of the term itself or a general model of the area in which the term is involved.

Dissemination of information. Infological models added with properly configured API make it possible to automate information dissemination. The peculiarity of this application consists in the coherence of information disseminated: the portal receiving data is not limited by the transmitted infological model and can provide users with a model-linked content, of course, if this is allowed by the source portal.

\subsection{News portals}

The quality of the news portal is determined not only by the quality of news articles placed therein, but also by their reliability and time of occurrence. As of today, the speed of indexing the biggest news portals by search systems takes a few minutes from the beginning of indexing before the page enters the search samples, and therefore, the issue of efficiency and control of the news source is particularly hot-bottom.

Due to the structure of the technology of the infological models, their usability can offer a number of unquestionable advantages to news portals: high quality of information visualization, promptness expansion of data dissemination, high reliability of borrowed fragments of articles, completeness of data proposed to users and possibility of automated analytics of the posted content.

The most important capabilities offered by the technology to news portals are as follows:

$\diamond$ Rapid dissemination of information. Due to automation of the process of distribution of infological models and their fragments, it becomes possible to implement a semi-automatic posting of news articles on the portal; this significantly reduces the time required for preparation of news to be posted on the agency's website;

$\diamond$ Management of information dissemination. Properly configured APIs make it possible to automate the process of information dissemination and control it by defining the access policy and data borrowing. This also makes it possible to automate the monitoring and analysis of information dissemination, all of which opens up new prospects for the news agencies;

$\diamond$ Monitoring of the datasource. Allinfologicalmodels borrowed from third party resources keep the designation of the data source, thereby facilitating monitoring of the source and tracking of the information channels.

\subsection{On-line shops}

The directory tree, its interface and service of automatic recommendations were and remain one of the key issues in the context of developing on-line shops. Due to powerful capabilities of automatic analysis of the posted information, infological models serve as powerful tools in relation to the afore mentioned problems.

In addition to the high quality of data visualization as described above, the use of infological models can bring a number of notable advantages to on-line shops: informational contents of description of goods and good categories, flexibility of the directory tree being used at the site, 
automation of handling processes for information posted on the site, powerful capabilities of automated analytics of the commodity grid and manageable data exchange.

Among the capabilities accessible for on-line shops in the course of applying the technology of infological models, three key capabilities can be identified:

- 'Smart' cross-sale modules filled based on analysis of the commodity grid and recommendations of postsales analytics. When infological models are properly configured, the recommendations of the entire sets of additional accessories can be automated.

- Updated and coherent knowledge base. The knowledge base containing recommendations on key goods categories is becoming more urgent in specialized on-line shops. Infological models can not only improve visualization, but also automate information uploads on the goods sites and filling of the bases with new data.

- Structured and controllable sales catalog. It becomes possible for on-line shop clients to use both a new access interface, and a new tree management interface for the internal employees. The change of the catalog tree can be turned into rebinding of the catalog infological model nodes to new menu items on the site.

\subsection{Smart house and the Internet of Things}

The concept of the Internet of Things is experiencing rapid growth, though the full implementation of the idea of easy management of things via the Internet causes a number of problems, principally noncooperation of the manufacturers and developers in relation to the API and interfaces used.

Due to differences in the hardware and software interfaces, it becomes impossible to create a common platform for managing things under control, and that, in turn, adversely affects the development of the area as a whole.

Application of the infological models as a means of monitoring and visualization of indicators can solve a part of the problems identified, bringing the following advantages to the Internet of Things: a high usability level, informational contents of working models, unification of the user interface to manage the things, automated monitoring and analytics of indicators, as well as a high degree of adaptability to new devices.

In the long view of using the infological models for the Internet of Things, the following significant capabilities can be identified:

$\diamond$ API for data systemization and exchange on a singlesolution platform. Since the infological models can be represented by an independent data visualization level from the Internet of Things devices, the aggregated data become available for any computerized analysis through customizable API;

\& Monitoring and analysis of indicators. The intuitive interface and high information content provide the user with a convenient tool to track aggregable indicators. In addition, data coherence and machine-reading facilitate automated analysis of the collected indicators. For example, we can determine in which room the power consumption is unreasonably high, or find out whether all electrical appliances are switched off.

By the example of the figure "Infological models in the scope of smart house," it is shown what the smart house interface built on the basis of the infological model could look like. The green color indicates low power consumption, while the blue color indicates a high power consumption. In so doing, data falling on the models are dynamic and are being updated in real time.

What happens if you go down to the next detail level of the concept, to a separate room? You can see items included in the content of a selected room and move to their management. The following example opens a view of a separate room based on the infological models interface (Figure 9).

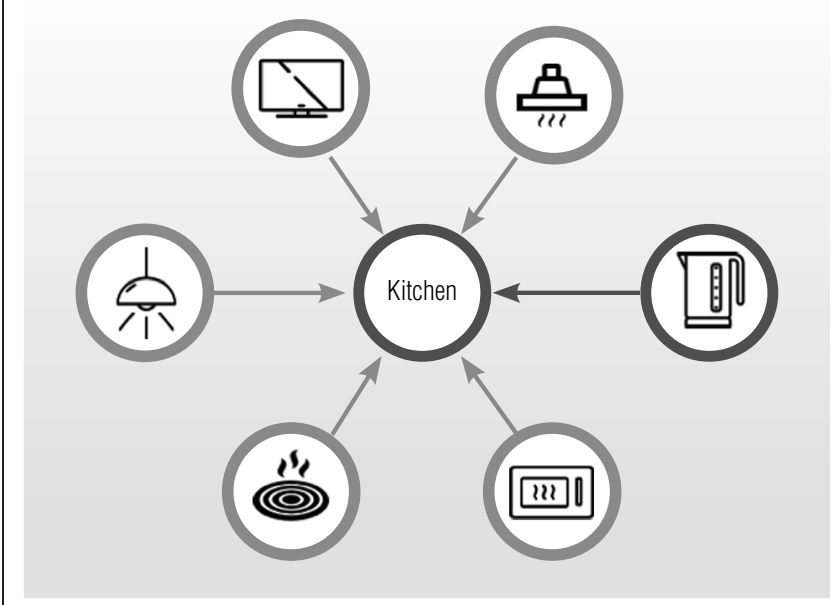

Fig. 9. Concept of the smart house room interface

\subsection{Event logging}

In addition to the identified capabilities, a list of recorded events associated with the selected subject can be logged in a separate subject of the infological model. For example, periods of kettle operation and electricity consumption graph. The historicity of the data provided, while maintaining a high level of usability, is a distinct advantage of the technology. 
Therefore, the usability of the technology is of an extensive nature - from a point tool for e-commerce sites to a multipurpose platform combining standards and technologies. To some extent, it is due to a new approach to information visualization and consequent improved human perception of data; to some extent it is caused by information processing capabilities offered by the use of infological models in modern business areas and life.

\section{Conclusion}

During the research, modern data processing technologies and information visualization methodologies were analyzed. The results of studies and papers which have found their ways in the world scientific literature were also interpreted.

The analyzed material and the results obtained during the study provided the basis for designing and developing a technology of infological models incorporating key features of information processing and visualization. Thus, the tasks set for the research were solved, and the goal of creating a new effective method of data visualization and information handling was achieved.

Using the findings obtained during the study by the Netbell ${ }^{1}$ project team, a technology of infological mod- els with the following features was designed and implemented:

$\diamond$ high efficiency of news and data exchange;

$\diamond$ monitoring of data sources;

$\diamond$ information flow management;

$\diamond$ integrity and coherence of the data provided;

$\diamond$ automated generation of customer-focused pages;

$\diamond$ automated analytics of input information;

$\diamond$ a host of other things, depending on the area of the technology application.

The final part of the study describes the usability of infological models in e-business as seen in information portals, knowledge bases, news portals, on-line shops, the Internet of Things and smart houses, as well as the technical basis required for implementation of the technology.

It should be noted that the use of the technology of infological models is possible even today, and it offers some important challenges, i.e. improving the human perception of information, development of "smart" commerce, as well as systematization and automation of information processing.

This article is an extended version of the material presented at the IEEE Conference on Business Informatics in 2016 .

\section{References}

1. Baber C., Andrews D., Duffy T., McMaster R. (2011) Sensemaking as narrative: Visualization for collaboration. Proceedings of the Third International UKVAC Workshop on Visual Analytics (VAW 2011), 7-8 September 2011, University College London, UK, pp. 7-11.

2. Baber C., Andrews D. (2014) Visualizing interactive narratives: Employing a branching comic to tell a story and show its readings. Proceedings of the 32nd Annual ACM Conference on Human Factors in Computing Systems (CHI 2014), 26 April - 01 May 2014, Toronto, Canada, pp. 1895-1904.

3. MacEachren A.M., Monmonier M. (1992) Geographic visualization: Introduction. Cartography and Geographic Information Science, no. 19, pp. 197-200.

4. Averbukh V.L. (2006) Metafora interfeysa i metafora vizualizatsii. Kakaya teoriya nam nuzhna? [Interface metaphor and visualization metaphor. Which theory do we need?]. Proceedings of the 16th International Conference on Computer Graphics and Applications (GraphicCon 2006), 1-5 July 2006, Novosibirsk, Russia, pp. 262-268 (in Russian).

5. Averbukh V.L., Bakhterev M.O., Baydalin A.Yu., Gorbashevskiy D.Yu., Ismagilov D.R., Kazantsev A.Yu., Nebogatikova P.V., Popova A.V., Vasev P.A. (2008) Searching and analysis of interface and visualization metaphors. Human computer interaction: New developments, K. Asai (Ed.). Available at: http://www.intechopen.com/books/human_computer_interaction_new_developments/searching_and_analysis_of_interface_and_visualization_metaphors (accessed 01 September 2016).

6. Segel E., Heer J. (2010) Narrative visualization: Telling stories with data. Visualization and Computer Graphics, IEEE Transactions, vol. 16, no. 6, pp. 1139-1148.

7. MacEachren A.M. (1995) How maps work: Representation, visualization, and design. N.Y.: Guilford Press.

8. Cooper A. (2004) The inmates are running the asylum: Why high-tech products drive us crazy and how to restore the sanity. Indianapolis: Sams Publishing.

9. Bier E.A., Card S.K., Bodnar J.W. (2008) Entity based collaboration tools for intelligence analysis. Proceedings of IEEE Symposium on Visual Analytics Science and Technology (IEEE VAST '08), 19-24 October 2008, Columbus, Ohio, USA, pp. 99-106.

10. Noyes J., Baber C. (1999) User-centred design of systems. Springer Verlag.

${ }^{1}$ Information on the developer is available at http://netbell.ru 


\title{
Инфологические модели для умной коммерции
}

\author{
К.А. Князев \\ директор компании «Нетбелл»; \\ аспирант кафедры инноваций и бизнеса в сфере информационных технологий \\ Национальный исследовательский университет «Высшая школа экономики» \\ Адрес: 101000, г. Москва, ул. Мясницкая, д. 20 \\ E-mail: kk@netbell.ru
}

\section{M.M. Комаров}

кандидат технических наук, доцент кафедры инноваций и бизнеса в сфере информационных технологий Национальный исследовательский университет «Высшая школа экономики»

Адрес: 101000, г. Москва, ул. Мясницкая, д. 20

E-mail:mkomarov@hse.ru

\begin{abstract}
Аннотация
В современном обществе навыки работы с информацией играют ключевую роль, растет влияние информации на развитие общества. В последнее время стремительно увеличиваются объемы генерируемой информации, однако методы ее обработки остаются прежними.

Исследование посвящено проблемам обработки и визуализации информации, с каждым годом приобретающими все большую популярность. Цель работы - разработать новый метод визуализации данных и работы с информацией на основе технологий представления информации, а также принципов семантических сетей, открытых данных и банков данных.

Технология инфологических моделей представляет собой новый подход к хранению и обмену данными, позволяющий взглянуть на работу с информацией с новой стороны. Базируясь на принципах открытых данных, семантических сетей и банков данных, концепция решения заключается в том, чтобы определить набор субъектов и связей, на базе которых можно отображать отдельный информационный блок в виде блоксхемы (графа), понятного как рядовому пользователю, так и компьютеру.

Работа содержит краткий обзор проблемы избытка информации, описывает технологию инфологических моделей и ее основополагающие принципы, содержит анализ использования инфологических моделей в электронной коммерции на примере применения при организации баз знаний, новостных порталов, Интернет-магазинов, умных домов и Интернета вещей. Также описываются ключевые особенности и преимушества решения с выводами на базе проведенного исследования.
\end{abstract}

Ключевые слова: инфологические модели, представление знаний, умная коммерция, семантика, визуализация данных, открытые данные, банки данных, семантические сети.

Цитирование: Kniazev K.A., Komarov M.M. Infological models for smart commerce // Business Informatics. 2016. No. 4 (38). P. 19-26. DOI: 10.17323/1998-0663.2016.4.19.26.

\section{Литература}

1. Baber C., Andrews D., Duffy T., McMaster R. Sensemaking as narrative: Visualization for collaboration // Proceedings of the Third International UKVAC Workshop on Visual Analytics (VAW 2011), 7-8 September 2011, University College London, UK. 2011. P. 7-11.

2. Baber C., Andrews D. Visualizing interactive narratives: Employing a branching comic to tell a story and show its readings // Proceedings of the 32nd Annual ACM Conference on Human Factors in Computing Systems (CHI 2014), 26 April - 01 May 2014, Toronto, Canada. 2014. P. $1895-1904$.

3. MacEachren A.M., Monmonier M. Geographic visualization: Introduction//Cartography and Geographic Information Science. 1992. No. 19. P. 197-200.

4. Авербух В.Л. Метафора интерфейса и метафора визуализации. Какая теория нам нужна? // Proceedings of the 16th International Conference on Computer Graphics and Applications (GraphicCon 2006), 1-5 July 2006, Novosibirsk, Russia. 2006. P. 262-268.

5. Searching and analysis of interface and visualization metaphors. V.L. Averbukh [et al.] // Human computer interaction: New developments / K. Asai (Ed.). 2008. [Электронный ресурc]: http://www.intechopen.com/books/human_computer_interaction_new_developments/searching_and_analysis_of_interface_and_visualization_metaphors (дата обращения 01.09.2016).

6. Segel E., Heer J. Narrative visualization: Telling stories with data // Visualization and Computer Graphics, IEEE Transactions. 2010. Vol. 16. No. 6. P. 1139-1148.

7. MacEachren A.M. How maps work: Representation, visualization, and design. N.Y.: Guilford Press, 1995.

8. Cooper A. The inmates are running the asylum: Why high-tech products drive us crazy and how to restore the sanity. Indianapolis: Sams Publishing, 2004.

9. Bier E.A., Card S.K., Bodnar J.W. Entity based collaboration tools for intelligence analysis // Proceedings of IEEE Symposium on Visual Analytics Science and Technology (IEEE VAST '08), 19-24 October 2008, Columbus, Ohio, USA. 2008. P. 99-106.

10. Noyes J., Baber C. User-centred design of systems. Springer Verlag, 1999. 